\title{
318. シャウカステンの管理 一忠暗くてもいのか?-
}

Quality control of view box - Why stay ill when it is Iightened up ?-

\begin{tabular}{|c|c|c|c|c|c|c|}
\hline 越谷市立病院 & 放射線科 & $\begin{array}{l}\text { ○遠藤 } \\
\text { (Hidek }\end{array}$ & $\begin{array}{l}\text { 英樹 } \\
\text { Endo) }\end{array}$ & $\begin{array}{c}\text { 堤 } \\
\text { ( } \mathrm{S} \text { u } \mathrm{Buba}\end{array}$ & $\begin{array}{l}\text { 直葉 } \\
\text { Tsutsumi) }\end{array}$ & $\begin{array}{l}\text { 阿部 正己 } \\
(\text { Masaki Abe) }\end{array}$ \\
\hline & & 真野 & 㺊 & 高村 & $\begin{array}{l}\text { 明宏 } \\
\text { 。 Tak a mur }\end{array}$ & \\
\hline
\end{tabular}

【目的】当院では、昭和63年 7月よりシャウカス テンの照度管理を始めた。しかし、照度が大幅に翼 なるにもかかわらず、診断する医師側からはクレ ムはなかつた。そこで、シャウカステンはなぜ暗く ても良いのかについて、照度の違うシャウカステン を朋いて視覚評価を行い、シャウカステンの管理は どうすべきかを娭討したので報告する。

【方法及び結果】たな使用器具：照度計／トソコリ IM 2D - 輝度計 /BM-8・濃度計/マクヘス TD931

(1)放射線科内のシャウカステンの現状を調べた。台 数は49台、そのうち41台について照度管理を行って いる。(2)シャウカステンの照度と輝度の関係を濃度 のわかつたX線つィルムを用いて調べた。図 1 に示 すような相関関係を得た。(3)シャウカステンの横方 向の照度を $2 \mathrm{~cm}$ 間隔に測定した。人間の目では判別 できないムラがあった。(4) 3 力月毎に照度計でシャ ウカステンの中心とそのト下布有 $5 \mathrm{~cm}$ の点を测定し、 5 点の平均をシャウカステンの照度としその推移を みた。戍2において更新したものを除いては、17カ 月間に大幅な変動はない。(5)八ウレットチャ トを アクリル板にはさんでF C R で撮影し、濃度の違う 写真を作成した。それを用いて照度の違うシャウ力 ステンで視覚評価を行った。その結果を図3 亿示す。 まとめると、高輝度シャウカステンでは低濃度部が、 低輝度シャウカステンでは高溲度部がそれぞれ読み にくかった。

【考察及び結論】(1)シャウカステンの明るさを测 定する場合輝度計の方が良いが、QC業務において は蛼度部を用いることは困難であることから、相関 関係もあり、测定が容易な照度計を使用した。(2)シ ヤウカステンは調光式のものか、せめて照度が 2 段 切替え式のものが望ましい。また、写真周用の光の 影響を考えると、部分点灯叮能なものも必要である。 (3)視覚評価において、読加くさということを表現 するのは難しい。この読みにくいが読めるという点 でシャウカステンは暗くてもクレ -ムがつかないの ではないかと思われる。(4)奏際の臨休写真を読影す るときにシャウカステンの照度の違いが、臨柝情報 を得るのにどれだけ影響するのかは不明だが、今回 の央験結果より照度管理を行う必要があると考える。
四1シャウカステンを用いた、 照度と輝度の相関関係

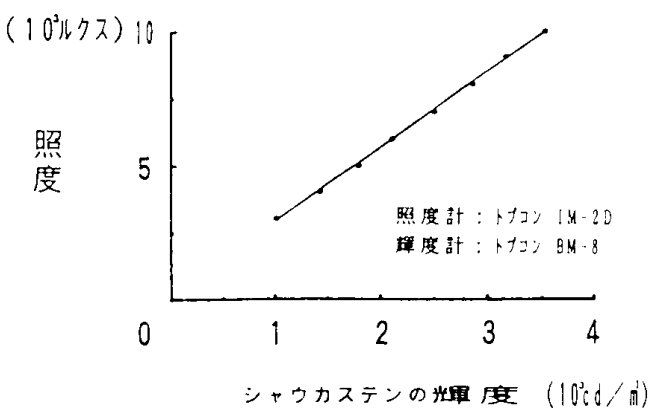

因2シ氻矿照度の経時变化

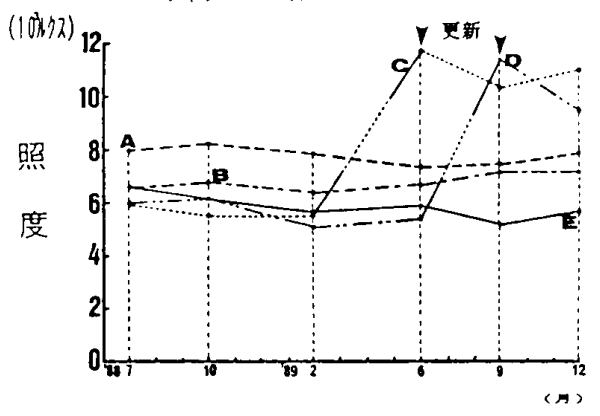

図 3 濃度を变えた試料の視覚評価 （異恬名照度のシャクカステンを用いて）

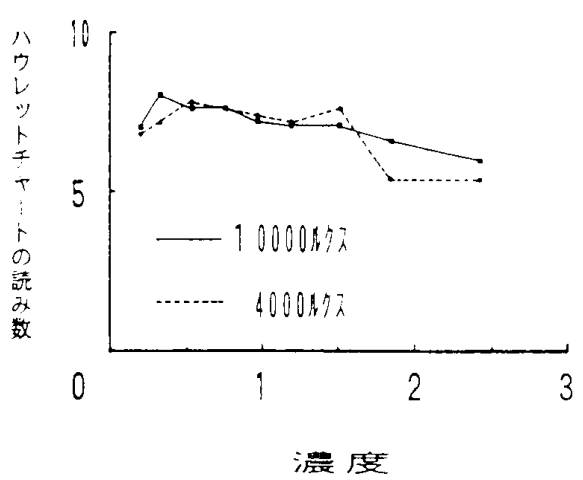

